ELORE (ISSN 1456-3010), vol. 20 - 2/2013.

Julkaisija: Suomen Kansantietouden Tutkijain Seura ry.

[http://www.elore.fi/arkisto/2_13/pk_hytonen-ng_lukin.pdf]

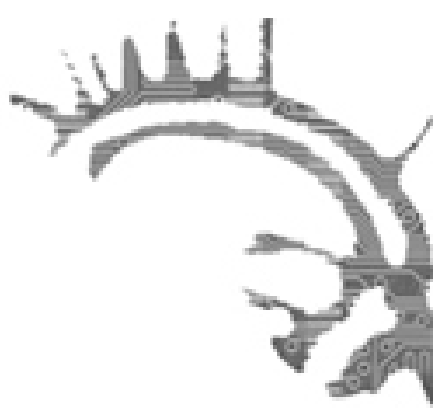

\title{
PäÄKIRJOITUS
}

\section{KOVIA ARVOJA}

\author{
Elina Hytönen-Ng \& Karina Lukin
}

Tämän vuoden merkittävimpiä perinnepoliittisia ja -tieteellisiä keskusteluja on käyty Salon Seudun Sanomien sivuilla. Salon Rikalanmäellä järjestettiin elokuun alussa Rituaaliviikko, tapahtuma, jossa rituaalia tutkittiin sekä perinteisen esinenäyttelyn, teatterin, arkeologisten esitelmien että muiden rituaalia koskettavien esitelmien välityksellä. Tapahtuman taustalla oli joukko kulttuuritoimijoita, jotka haluavat perustaa Rituaalimuseon ja käyttää Rikalanmäkeä tukikohtanaan (ks. Rituaalimuseo). Taloudellisia takapakkeja kokenut kaupunki näytti museolle ensin vihreää valoa, kunnes paikallinen kulttuuriväki ryhtyi äänekkäästi vastahankaan. Rituaalimuseon toimijat vastasivat lehden mielipidepalstalla samalla voimalla. Koko museon käsitettä ravisteleva konsepti ja kansallisten tukirakenteiden ulkopuolella toimiva organisaatio lienee Salolle - tai kenties koko Suomen muistiorganisaatiokentälle - liian haastava kokonaisuus.

Rituaalimuseon toiminta-ajatus liittyy aineellisen ja aineettoman kulttuuriperinnön välimaastoon. Sen toimijat haluavat yhdistää erilaisen tietämisen ja kokemisen tapoja ja kannustaa ihmisiä pohtimaan rituaalia näiden kautta - joko ääneen tai muassaan. Rituaalimuseolla on paikkansa: vieraantuminen uskonnosta ei ole tarkoittanut ainoastaan sekularisoitumista vaan myös sitä, että ihmiset eivät enää tunne uskontoja tai uskonnollisia ajattelun tapoja. Rituaaleja nähdään siksi mieluusti muilla, mutta ei meillä.

Perinnetieteillä on paikkansa näissä keskusteluissa ja sikäli myös yhteiskunnassa - ja Rituaalimuseon toiminnassa. Perinnetieteiden asema ei ole enää kansallisessa kontekstissa, kuten Tuomas M. S. Lehtonen toteaa tämän lehden katsauksessaan. Perinnetie- 
teillä on huimasti tarjottavaa ennen kaikkea tämän päivän monikulttuuristen prosessien avaamisessa, mutta myös monien arkisten toimien ja yhteiskunnallisten keskustelujen ja niissä toistuvien uskomusten ja väitteiden erittelyssä. Esimerkiksi internetissä, jota Anne Heimo kannustaa katsauksessaan pitämään yhtenä tutkimuskenttänä.

Tässä Eloren numerossa käydään, Lehtosen katsauksen lisäksi, erityisesti ajankohtaistapalstan teksteissä keskustelua folkloristiikan luonteesta ja asemasta yhteiskunnassa ja folkloristien metafolkloristisesta keskustelusta. Folkloristien kriisipuheen kansainväliset ulottuvuudet ovat tulleet tänä vuonna hyvin esiin esimerkiksi ISFNR:n konferenssissa, SIEF:in sisältä nousseissa pyrkimyksissä poistaa "folklore" yhdistyksen nimestä (ks. raportit tässä Eloressa), mutta myös American Folklore Societyn konferenssissa, jossa helsinkiläisten folkloristien joukko vieraili lokakuussa. Kriisipuhe on osittain osa luonnollista humanistisen tieteenalan keskustelua: eteenpäin pyrkivä ja kunnianhimoinen tutkija tarkastelee itseään ja alaansa ankarasti ja luovii siksi mutkattomasti kriisin ja hybriksen aallokossa. Mutta kuten Diane Goldstein totesi AFS:n lopettaneessa puheenvuorossaan, kriisipuhe sijoittuu myös osaksi kaavaa, jossa yhteiskunnan valtapiirien toimintaan kriittisesti suhtautuvat folkloristit kieltäytyvät antamasta panostaan, koska epäilevät osallistuvansa epäeettiseen toimintaan. Vaikenemista seuraa valitus siitä, ettei folkloristien mahdollista asiantuntemusta arvosteta, kun asiantuntijoiksi otetaan muita.

Goldsteinin lääke ei ollut laventuminen tai liudentuminen, vaan äänen voimakkuuden nostaminen. Vastaavalla tavalla akateemikko Anna-Leena Siikala kehottaa tässä Eloren numerossa julkaistussa haastattelussaan folkloristeja kirjoittamaan suomalaiselle yleisölle ja pohtimaan rooliaan yhteiskunnassa. Siikalan Itämerensuomalainen mytologia (2012) on hyvä esimerkki siitä, ettei folkloristisen asiantuntemuksen tarvitse aina taipua suoraan yhteiskunnan sovellettavaksi tai koskea nykyaikaa: myös laadukas tutkimus kiinnostaa.

Folkloristien asiantuntemus kerronnan tavoista, luonteesta ja muodoista sekä näiden kiinnittymisestä yksilölliseen, yhteisölliseen ja yhteiskunnalliseen kokemukseen kohdistuvat, Juha Sihvolan $(2004,289)$ sanoin, koviin arvoihin, "jotka kaikkein syvällisimmin ja voimakkaimmin vaikuttavat yhteiskunnan kehitykseen". Asiantuntemus nousee sekä aikaa vievästä perustutkimuksesta, ihmisten kuulemisesta ja kuuntelemisesta että syvällä antaumuksella ja sydämellä tehdystä analyysistä. Sen sovellusalueet ovat kaukana menneisyydessä tapahtuneiden esitysten ja nykypäivän kommunikaation sekä tulevaisuuden käytänteiden parissa - siellä, missä ihmiset toimivat keskenään ja missä heillä on tarve ymmärtää toistensa kokemuksia.

\section{ELORE 2 / 2013}

Nyt käsillä olevan Eloren tutkimusartikkeleissa syvennytään suomalaiseen kulttuuriympäristöön liittyviin aiheisiin. Vaikka artikkelien aineistot on kerätty aivan äskettäin joko kenttätöissä tahi sanomalehdistä, ulottuvat tulkinnan horisontit perinnetieteille totunnaiseen tapaan menneestä löytyviin jatkuvuuksiin. Heidi Haapojan artikkelin jatkuvuudet ovat omaan alaamme liittyvissä keskusteluissa perinteestä. Anna Kinnunen taas tarkastelee artikkelissaan, miten mielikuvien jatkuvuuksia kiistetään implisiittisesti mielisairautta koskevissa haastatteluissa. 
Ajankohtaista-palstalla julkaistaan jo mainittujen teemojen lisäksi runsaasti konferenssiraportteja ja lektioita sekä tasavuosia tänä vuonna juhlivan akateemikko Anna-Leena Siikalan haastattelu. Kaikkia, lukuisia Eloren käsikirjoituksia työstäneitä toimittajia käy kiittäminen tinkimättömästä työstä! Lisäksi haluamme kiittää nimettömäksi jääviä asiantuntija-arvioijia, joiden kannustavat ja kriittiset kommentit ovat auttaneet sekä toimitusta että artikkelien kirjoittajia.

Tämän lehden päätoimittajina ovat toimineet Elina Hytönen-Ng ja Karina Lukin, joka on ottanut kopin äitiyslomalle jääneeltä Sofie Strandén-Backalta. Sofie ei enää palaa Eloreen - toimitus kiittää lehdelle ja sen ennakkoluulottomalle kehittämiselle sitoutunutta Sofieta ja onnittelee pienen ihmisen syntymisestä! Jo täysi-ikäinen Elore täyttää ensi vuonna 20 vuotta, minkä juhlintaa on toimituksessa suunniteltu hartaudella. Juhlavuosi tuo mukanaan myös uusia tuulia ja lisää muutoksia: päätoimittajana vuodesta 2012 toiminut Elina Hytönen-Ng on jättämässä tehtävänsä vuoden 2014 aikana, ja hänen tilalleen etsitäänkin uusia kasvoja ja ideoita. Edessä on siis varsin mielenkiintoinen ja haastava juhlavuosi. Ensi vuotta kannattaa siis odottaa, mutta malttakaa lukea ja nauttia ensin tästä numerosta!

\section{KirJallisuUS}

RITUAALIMUSEO: [online] <http://rituaalimuseo.fi/> [29.10.2013.] SIHVOLA, JUHA 2004: Maailmankansalaisen etiikka. Helsinki: Otava. SIIKALA, ANNA-LEENA 2012: Itämerensuomalainen mytologia. Helsinki: SKS. 